\title{
In Search of the Truth: Uncovering Nursing's Involvement in Colonial Harms and Assimilative Policies Five Years Post Truth and Reconciliation Commission
}

\author{
Paisly Michele Symenuk ${ }^{1}$, Dawn Tisdale ${ }^{2}$, Danielle H. Bourque Bearskin ${ }^{3}, \&$ Tessa Munro ${ }^{4}$ \\ ${ }^{1}$ School of Population \& Public Health/School of Nursing, The University of British Columbia, ${ }^{2}$ School \\ of Nursing, The University of British Columbia, ${ }^{3}$ School of Nursing, McMasters University, ${ }^{4}$ Independent \\ Author.
}

Cite as: Symenuk, P., Tisdale, D., Bourque Bearskin, D.H. \& Munro, T. (2020). In Search of the Truth: Uncovering Nursing's Involvement in Colonial Harms and Assimilative Policies Five Years Post Truth and Reconciliation Commission. Witness: The Canadian Journal of Critical Nursing Discourse, Vol 2(1), 84-96 https://10.25071/2291-5796.51

\begin{abstract}
The year 2020 marks five years since the Truth and Reconciliation Commission (TRC) of Canada released its Calls to Action, directing nursing to take action on both "truth" and "reconciliation". The aim of this article is to examine how nurses have responded to the TRC's call for truth in uncovering nursing's involvement in past and present colonial harms that continue to negatively impact Indigenous people. A narrative review was used to broadly examine nurses' responses to uncovering nursing's complicity in five colonial harms: Indian hospitals, Indian Residential Schools, child apprehension, Missing and Murdered Indigenous Women and Girls (MMIWG), and forced sterilization. The paucity of results during the post-TRC period demonstrates a lack of scholarship in uncovering the truth of nursing's complicity in these systems. Based on findings, we explore two potential barriers in undertaking this work in nursing, including a challenge to the image of nursing and anti-Indigenous racism.
\end{abstract}

Keywords: nursing, Indigenous Peoples, colonialism, racism, Canada

"You don't get to argue with them and say, 'well that's not true and I didn't do that, and I didn't mean this.' You don't get to judge the harm when you inflict it. Then you have to accept that harm as fact. You don't get to debate it later. You don't get to analyze it later; it's fact."

-Dr. Pam Palmater (2018)

Corresponding Author: Paisly Michele Symenuk, School of Population \& Public Health/School of Nursing, 


\section{Background}

Released in 2015, the Truth and Reconciliation Commission of Canada (TRC) report highlights the genocidal actions perpetrated against Indigenous people since first contact in the lands now known as Canada (TRC, 2015a). Of concern for the nursing profession, when discussing the rights and health of Indigenous Peoples, is the TRC's Calls to Action report. Of the seven institutions identified in this report, the section dedicated to Health speaks to treaty rights, closing the gap on health outcomes between Indigenous Peoples and settlers, funding mechanisms, education, and Aboriginal healing (TRC, 2015a). Call to Action \#24 calls upon schools of nursing to integrate Indigenous-specific content on colonialism and Indigenous health, requiring that cultural competency and cultural safety are integrated into curricula and mandated for educators ( $\mathrm{p}$. 211).

While nursing is explicitly named in Call to Action \#24, each of the seven Calls to Action within the health section have implications for the nursing profession to adopt and operationalize. Additionally, nursing has a considerable stake outside of the health sector due to the diverse positions nurses occupy across public sectors and the influence they hold as one of the largest civil service professions in Canada. As the largest workforce in the Canadian health care system, the Calls to Action on health must take on a greater focus with more urgency for the nursing profession.

In a post-TRC era, nursing organizations, policy leaders, and educational institutions continue to grapple with how to implement and enact reconciliation. Missing from this discourse is building on the TRC's mandate to fully understand nursing's complicity in colonial harms by engaging in nursing's truth. The TRC calls on specific professions to examine the truth within their discipline, in order to understand and address the harms that need to be accounted for (TRC, $2015 \mathrm{a}, \mathrm{p}$. iv). The commissioners outline that, "in order for that [reconciliation] to happen, there has to be an awareness of the past, acknowledgment of the harms that have been committed, atonement for the causes, and action WITNESS to change behaviour" (TRC, 2015a, p. 6). Uncovering the truth of nursing within the context of colonial harms is vital in supporting nursing's work towards reconciliation.

When the nursing profession considers its role within the work of reconciliation, it is vital to establish what issues need to be addressed and how the work of reconciliation is contextualized. The preface of the TRC summary report states, "Reconciliation is not an Aboriginal problem; it is a Canadian one" (TRC, $2015 \mathrm{a}, \mathrm{p}$. vi). Framing the health inequities that impact Indigenous people as 'Indigenous issues' rather than 'colonial issues' that stem from ongoing colonization and anti-Indigenous racism diverts attention away from those implicated in colonial structures (nursing) to do the heavy lifting of reconciliation. In order to address the problems of the past and present, nursing must first be willing to take a critical look at its truth. An example of a report addressing the truth in the context of their respective profession is the Royal Canadian Mounted Police's (RCMP) report titled The Role of the RCMP During the Indian Residential School System (LeBeuf, 2011). After reviewing publications by nursing associations, unions, and colleges, it appears that there has been no similar work done in the context of the nursing profession regardless of jurisdiction or mandate.

Over the past five years, nursing organizations, service-providing institutions and schools of nursing have questioned what nursing's role is in the process of enacting reconciliation. Nursing asks: What does reconciliation look like? What can the nursing profession do to action reconciliation? Contrastingly, a focus on the 'truth' has remained largely absent or secondary to nursing discussions about reconciliation, as we describe through the literature in this paper. Perhaps nursing operates under the assumption that the work done by The Truth and Reconciliation Commission of Canada was the work needed to uncover the truths needed to guide future nursing policy.

Alternatively, perhaps there is an assumption that nursing has undertaken a robust body of work, bringing to light how nursing has engaged in acts of assimilation and colonial

VOL. 2(1) 
harms towards Indigenous people. We contend, five years post-TRC, that the nursing profession in Canada has not undertaken the work required to uncover the full extent of its role in colonization, contributing to the removal of rights and freedoms of Indigenous people and causing colonial harms. If nursing does not have a comprehensive understanding of what needs to be reconciled within the relationship between the nursing profession and Indigenous Peoples, then reconciliation cannot be attained. Without widely and deeply examining nursing's role within colonial health systems that have and continue to perpetuate harm, the profession will continue to locate itself as committed to reconciliation, but not complicit in the truth of these harms. To examine the extent to which nursing has taken action to engage with its role in past and present colonial harms, we examine nursing scholarship on five systems of colonial harm and discuss the implications of our findings concerning the nursing profession and reconciliation with Indigenous peoples in Canada.

While reading this manuscript, there may be an instinctive response to think, "not all nurses were harmful." This is neither the purpose, not the intent of this paper. We encourage readers to circle back and revisit the purpose of this paper as many times as needed while reading. This response may also act as an instrument that intentionally or unintentionally derails, detracts, and dismisses the very real violence and harm that Indigenous Peoples have faced at the hands of nursing and nurses. Instead, we encourage readers toward Nīpawīstimatowin, or to "bear witness for one another," just as this special issue calls us to do.

\section{Nursing's Implications in Colonial Harms \& Assimilative Policies}

To begin to examine how nurses and the nursing profession have been active participants in colonial harm historically and today, we introduce five systems and institutions that nursing has played a significant role in or continues to. These five colonial systems and institutions are: Indian hospitals, Indian Residential Schools, child apprehension, Missing and Murdered Indigenous Women and WITNESS
Girls (MMIWG), and forced sterilization. The systems selected for the purposes of this research were chosen due to their widespread recognition within the Canadian context during the post-TRC years. These five examples are in no way exhaustive of all the systems and institutions nurses and the nursing profession have and continues to be a part of.

In addition, the intent of this paper is not to conduct the very work we are calling on nurses and the nursing profession to do in uncovering the profession's complicity in colonial harms. Instead, this article aims to examine how nurses have responded to the call for truth in uncovering and acknowledging nursing's involvement in colonial harms. The following offers a brief overview of the five systems and institutions under review, with a glimpse into the ways nurses are active participants historically and contemporarily. While we describe these systems and institutions separately, the reality is that they are intricately interconnected to one another, bound by assimilative policies and action to support the colonial project (Watson, 2016).

\section{Indian Hospitals}

With their roots in Christian missionary work, Indian hospitals began in the $20^{\text {th }}$ century and operated until 1981, acting as racially segregated, federal government-run institutions (Lux, 2018). While these institutions were called "hospitals," Lux (2016) states how Indian hospitals " ... operated to maintain if not widen health disparities" (p. 17). To further the government's agenda of segregation and assimilation, the Indian Act was amended in the 1950 s, making it a crime for Indigenous people to refuse care or leave Indian hospitals before discharge orders were made (Lux, 2018). These biomedical institutions were justified by citing the need to ensure the containment of tuberculosis in order to protect the settler population, and address the "Indian problem," also known as the place of Indigenous Peoples in the Canadian settler state (Lux, 2016; 2018). Non-Indigenous Peoples were not required to be contained in non-Indian hospitals (Hardy v. The Attorney General of Canada, 2018).

VOL. 2(1) 
Just like hospitals today, nurses were at the center of these institutions in management, nursing care, and as students (Drees, 2013; Lux, 2018). Each Indian hospital had a nurse matron (nurse supervisor) on the institution's senior staff who was in charge of all of the patient care and domestic work (Lux, 2016). Unlike settler hospitals, nurses working in Indian hospitals were not required to maintain licensure and rarely worked within nursing practice standards or ethics (Lux, 2016). Existing work on Indian hospitals implicates nurses at the forefront of physical, sexual, and psychological abuse including but not limited to forced kissing, feeding vomit to children, forced isolation, hitting children with belts, and the use of straitjackets and casts for restraining (Drees, 2013; Lux, 2016).

Furthermore, nurses retrieved children and adults from their communities to come to the Indian hospitals in "case-finding" missions (Drees, 2013; "Indian Health Services," 1951; Lux, 2016). Today, Canada's Indian hospitals are at the center of a \$1.1-billion class action lawsuit due to the harm, abuse, and deaths caused in these institutions (APTN National News, 2018; Federal Court of Canada, 2018). The Department of Indian Affairs, in addition to Indian hospitals, also ran a significant number of nursing stations and clinics that have yet to be examined robustly (Canadian Nurses Association [CNA], 1968; Lux, 2016). During the 1960s, 66 outpost nursing stations and 88 health centers were operating, each led by registered nurses (CNA, 1968).

\section{Indian Residential Schools}

Indian Residential Schools are now one of the most recognizable institutions of colonial harm in Canada, following the explicit focus on the legacy of residential schools brought forward by the TRC (2015a). These institutions, run by both Christian churches and the Canadian government, had the primary intention to assimilate Indigenous children into EuroCanadian society (Miller, 2020; TRC, 2015a). Nurses were stationed at Indian Residential Schools, either conducting nursing work or working as matrons and teachers (TRC, 2015b). Many students of Indian Residential Schools WITNESS saw their experiences intertwined with that of Indian hospitals, as the schools caused significant illness due to the dire conditions (Lux, 2016). One example is that care at Indian Hospitals was determined by those who showed progress in assimilation from the residential school system (Lux, 2016). Similar to the case for Indian hospitals, federal nurses took on the role of working with Indian agents to remove children from their homes and communities to take them to Indian Residential Schools (TRC, 2015c). Also described by students was the negligence and neglect of nurses having their illnesses dismissed or providing no care (TRC, 2015c).

\section{Child Apprehension}

The child apprehension system remains a significant source of historical and ongoing colonial harm. While some view social workers and the legal system as centrally responsible in the colonial harms perpetuated through child apprehension, nurses have been and continue to be at the forefront of care for children and families. Throughout the life course, nurses are in close contact with children and families, particularly in remote and rural areas, specifically in the practice areas of public health, community health, postpartum, and labour and delivery. Nurses in any care setting have a duty to report when, depending on the province, there is parental inability to care for a child or when there is a likelihood of harm (Public Health Agency of Canada, 2019). The role of nurses in child apprehension in Indigenous families must be uncovered fully both historically and in a contemporary context considering the pervasiveness of anti-Indigenous racism in Canadian health care (Allan \& Smylie, 2015; Boyer, 2017; Nestel, 2012). A recent report out of Saskatoon Health Region locates nurses in the process of child apprehension including incidents of anti-Indigenous racism, inconsistencies with charting, and communication with social workers (Boyer \& Bartlett, 2017)

While the term "Sixties Scoop" suggests a single decade in which Indigenous children were removed from their families, this system has spanned many decades (Blackstock, Trocmé, VOL. 2(1) 
\& Bennett, 2004; Crown-Indigenous Relations and Northern Affairs, n.d.; Sinclair, 2016). The total number of Indigenous children separated from their families remains unknown (Sinclair, 2016). In Canada, as of 2016, $52.2 \%$ of children under the age of 14 in foster care are Indigenous, compared to their representation as $7.7 \%$ of the child population in Canada; these numbers were unchanged from the 2011 census (Indigenous Services Canada, n.d.). Moreover, it must be recognized that the synergistically assimilative nature of both Indian hospitals and Indian Residential Schools operated through the legislated separation of families under the Indian Act (Lux, 2016). Lux (2016) describes how an Indigenous Health Services nurse characterized mothers as "negligent" for bottle-feeding their infants mixing formula using the only available water sources, which were sometimes contaminated, all while doing so in order to work. This nurse recommended that the children be apprehended and sent to a residential school immediately (Lux, 2016). One must consider that during the time this interaction took place, infant formula was regarded as a "well known, popular, and safe substitute for breastmilk" (Stevens, Patrick, \& Pickler, 2009, p. 36).

\section{Forced Sterilization}

Forced sterilization and other reproductive interventions, including unethical and targeted birth control and abortions, must also be considered when examining the role of nurses in colonial harms. Sterilization and other reproductive interventions were seen as a way to eradicate those who were "mentally defective" or had "undesirable qualities" (Stote, 2015, pp. $23,64)$ and, as such, disproportionately affected Indigenous Peoples, particularly women (Dyck, 2013; National Inquiry into Missing and Murdered Indigenous Women and Girls, 2019a). These issues are both contemporary and historical and must be considered as such. For example, sterilization historically occurred under the umbrella of public health (National Inquiry into Missing and Murdered Indigenous Women and Girls, 2019a). Head nurses in public health supplied lists of "undesirable families" to the government, and public health nurses led surveillance of those "unfit" for citizenship by WITNESS investigating homes (Dyck, 2013, p. 46). Furthermore, ward nurses conducted fallacious developmental and intelligence tests on children to identify those who had mental deficiencies (Dyck, 2013).

More recently, in 2017, an external review was conducted in the Saskatoon Health Region after reports of coerced tubal ligation in Indigenous women (Boyer \& Bartlett, 2017). This external review cites how nurses were involved, including coercion, harassment, unethical consent to procedures, and keeping women separated from their families during childbirth (Boyer \& Bartlett, 2017). Coercive and forced sterilization should remain an area of serious concern for nursing due to the proximity and leadership of nurses in labour and delivery, postpartum, and women's health settings.

\section{Missing and Murdered Indigenous Women and Girls (MMIWG)}

Most recently in Canada, a national inquiry was conducted focusing on missing and murdered Indigenous women and girls (National Inquiry into Missing and Murdered Indigenous Women and Girls, 2019a; 2019b). The final reports unpack the complex and compounding colonial harms that disproportionately affect Indigenous women and girls. Additionally, these reports begin to illustrate the intertwined and intergenerational effects of Indian hospitals, Indian Residential Schools, child apprehension, and forced sterilization on the systemic and sustained violence experienced by Indigenous women and girls (National Inquiry into Missing and Murdered Indigenous Women and Girls, 2019a; 2019b). Nurses are identified in these reports as practicing unethically and unprofessionally in both mental health and community settings (National Inquiry into Missing and Murdered Indigenous Women and Girls, 2019b).

Each of the systems and institutions discussed offer a glimpse into how nurses have been active participants in colonial harm. The extent of the impact these assimilative and colonial policies have had on the health and well-being of Indigenous peoples in Canada cannot be understated, nor can the extent to which nurses have participated and contributed 
(Tisdale \& McArthur, 2020). It is integral to note that since the $1950 \mathrm{~s}$, all licensed nurses in Canada were bound by a professional code of ethics (CNA, 1968). Since their inception, codes of ethics for nurses in Canada have always included explicit reference to their practice as nurses being unconditional regardless of nationality, race, creed, or colour (Tisdale \& Symenuk, 2020). We offer these five examples as only a mere starting point for the nursing community to begin the necessary work of interrogating a challenging and multifaceted aspect of the nursing profession that remains hidden.

\section{Methods}

To broadly examine the response to uncovering nursing's complicity in colonial harm, a narrative review method was employed. In alignment with the aim of this paper, a narrative review approach allows for a description and synthesis of a wide area of existing literature on a specific topic (Green, Johnson, \& Adams, 2006). The search strategy included the five systems and institutions described above: Indian hospitals, Indian Residential Schools, child apprehension, MMIWG, and forced sterilization. For each of the institutions or systems, the search terms were expanded to include various terminology used for referencing the same system (Appendix A). Due to the geographic and disciplinary focus of this review, both Canada and nursing were included in each of the searches. Each system was searched independently and conducted in CINAHL, Medline, PsycINFO, Scopus, and Web of Science limited to the years 2015 to 2019 (postTRC period). Only English language publications were included in the search. Results were not limited by study type, authors' discipline, or the field where the search terms appeared (i.e. in the title only versus in the keywords). Each of the results was reviewed by the abstract and title for relevance to the aim of this paper. Results were then analyzed, focusing on four key criteria: type of publication, where the result was published, whether the study focused on Indigenous Peoples or nurses and nursing, and what connection the result had to nursing. For each of the results, data was WITNESS extracted in alignment with the four key criteria. This data was then organized into a table where the results were synthesized by the authors to evaluate the nursing research and scholarship during the post-TRC period.

\section{Results}

Across the five selected databases using the five search term combinations, 16 articles were located. Eleven results were retrieved on Indian Residential Schools, five through the child apprehension search, and two results appeared in both searches. No literature was located for Indian hospitals, MMIWG, or forced sterilization during the post-TRC period. After review, two results were excluded having no relevance to the research aim. Of the fourteen results, twelve were published in peer-reviewed journals, and two were editorials in Canadian Nurse magazine. Of the peer-reviewed results, none were published in nursing journals. Rather, most articles were published in journals focused on Indigenous Peoples, health equity, or psychiatry. For example, one article was published in Transcultural Psychiatry, and two in International Indigenous Policy Journal.

After reviewing the results, it became clear that none of the fourteen articles discussed nurses or nursing's involvement in Indian Residential Schools or child apprehension. The articles appeared in our search results because each of them had at least one author from a school of nursing. Additionally, many of the results referenced nursing literature in their articles. Our results located nine peer-reviewed manuscripts based on empirical research, where each focused their work on Indigenous Peoples as participants, rather than a focus on nursing. The results largely centered on topics including mental health, violence, and substance use.

\section{Discussion}

These results highlight the need for action from the nursing profession, focusing on how nursing has and continues to participate in colonial harms. This inaction will continue to serve as a significant barrier to reconciliation for the nursing profession in Canada. Considering the lack of results through our search 
encapsulating the post-TRC period, one must question why nursing has not taken up this work. Smith (2019) calls for nursing to engage with its history "in a much more complex analytical way than it currently does" (p. 1). Smith also notes that nursing "must be ready to name and own its role in the creation and perpetuation of disparities" (p. 2). Nursing is home to some of the most prominent critical researchers, scholars, and historians who have the skillsets needed to complexly and comprehensively uncover nursing's complicity in colonial harm and assimilative policy. However, we suggest two connected potential barriers to undertaking this work in nursing. These include the image of nursing and anti-Indigenous racism.

While the image of nursing has been widely discussed in nursing scholarship, there has been an overwhelming focus on the importance of intervening on fictional portrayals of nurses as 'naughty,' loving mothers, or angelic handmaidens that devalue and delegitimize the profession (Gordon \& Nelson, 2005; Hallam, 2000; Kalisch \& Kalisch, 2005; Pike, 2001; Summers \& Summers, 2015). Additionally, nursing has been predominantly positioned throughout history as being oppressed, with nurses as victims on the receiving end of harmful systems, without complicating this image (Smith, 2019). These images stem from a complex web of influences including but not limited to the historical role of nurses, health care hierarchies, being a womendominated profession, and both the perceived and legitimate authority medicine and physicians hold in relation to nursing and nurses (Hallam, 2000; Pike, 2001). There is no doubt that these stereotypes and inaccurate depictions contribute to harmful outcomes for the way nursing is regarded, remunerated, and respected. We agree with the majority of extant literature in this area that has continued to call for nurses to contribute to a more accurate depiction of nursing.

However, this cannot only include the ways nursing has and continues to contribute skillfully and autonomously to health. There must be a concerted effort in also uncovering, naming, and owning participation in harmful systems and institutions.
Despite having a direct implication in colonial harms and assimilative policies, nursing has mostly been able to maintain an image of being good, moral, and benevolent (Gordon \& Nelson, 2005). Particularly, those who access health care largely see nurses "as 'good people' who care for others" (Finkelman \& Kenner, 2009, p. 93). The nursing profession is often touted as the most trusted profession, a title that is cherished and held proudly for its high currency. Gordon and Nelson (2005) label this as the "virtue script" and contend that nursing has relied on this due to the belief that this is nursing's "only legitimate source of status, respect, and self-esteem" (p. 67). However, in doing the work needed to uncover the historical and ongoing harms nursing has been complicit in, there is undoubtedly a fear of the profession losing its status of the most trusted profession in the eyes of the public. The image of nursing is further complicated by nurses' affinity to care and caring. Ten Hoeve, Jansen, and Roodbo (2013) found that caring was the most commonly identified concept in the development of self and professional identity for nurses. Uncovering nurses' and nursing's complicity in colonial harm challenges the very foundation of how nurses view themselves and the profession. However, images of nurses and nursing relating to goodness and caring amidst rampant racism in healthcare and the nursing profession create a significant paradox that must be deconstructed together in order to fully engage in this work of uncovering the truth.

While Canada's health care system is hailed worldwide as a champion for its universality and accessibility, the same cannot be said when referencing the experiences of Indigenous populations in Canada. After the United Nations established the UN Declaration on the Rights of Indigenous Peoples (UNDRIP), a UN Special Rapporteur investigated the rights of Indigenous people in Canada in 2013, concluding that the disparities between onreserve services and those available to nonIndigenous Canadian citizens are the most severe human rights violations present in Canada (UN General Assembly, 2014). The driving force behind these grave human rights violations concerning Indigenous peoples is racism. 
Racism operates by the overarching belief that one's race is superior to another's, and ultimately encourages discrimination that manifests as intolerance, stereotyping, and ostracism; racism is particularly useful in the hands of those with power (Reading, 2018).

Dominant narratives depict racism as a simple dichotomy of good and bad in that saying and doing acts of racism is equated to being a bad person, whereas morally 'good' people would not act in this way (DiAngelo, 2018). Understanding racism within a binary of good and bad is a barrier to uncovering the structural nature of racism and how it shapes all of our lives, and the inevitable ways in which we are conditioned into it (DiAngelo, 2018). This understanding of racism allows nurses to collectively place themselves outside of antiIndigenous racism rather than understanding racism as embedded within the system itself. This binary further allows us to view antiIndigenous racism as 'not our problem.' Placing nursing outside of work on anti-Indigenous racism, paired with the image of nurses and nursing being good and caring, provides a complex and compounding barrier to undertaking the first steps in uncovering the profession's complicity in colonial harms and assimilative policies.

Recognizing that limitations exist in all research, it is integral to acknowledge a few limitations that are present in this work. This review did not include published books. The authorship team chose to focus on published journal articles due to their major role in sharing and highlighting nursing research. Secondly, while our search terms were robustly built out by the authorship team, and searched independently across multiple databases, there may be additional terms that are synonymous to each of the five search areas undertaken. Lastly, as the focus of this review was to look at the post-TRC period, there may be literature that has written before this period, however, this is beyond the scope or purpose of this article.

\section{Conclusion}

Action across the TRC must be a priority for the nursing profession; however, the need remains for a vital body of work to support WITNESS this process. This action is the work of uncovering nursing's historical and ongoing complicity with colonial harms and assimilative policies. While this action is urgent, nursing should consider this an opportunity for the profession to be accountable for the ways nurses have and continue to harm Indigenous Peoples in Canada. It is nurses and nursing organizations, comprised of predominantly white settlers, who need to do the work of bringing the truth of anti-Indigenous racism in the profession moving forward. The burden of responsibility is not on Indigenous Peoples to teach Canadian nurses and nursing how to engage with the truth.

Similarly, the onus does not sit with Indigenous Peoples to share their stories of the harm nurses and nursing in Canada have done to them or their families. Nursing organizations and institutions host and have access to both current data and historical archives to work on bringing forward the more complicated truth of nursing's role in colonial harms. It is time for nurses, nursing organizations, and institutions to come together and invest in this work. Then and only then will nursing have an opportunity to begin working on the long journey of understanding where reconciliation is needed, and the harms that we cannot even begin to imagine the extent of.

\section{Ethical Permissions}

No ethical permissions were required due to the nature of this article, including published literature only and no human participants.

\section{Author Statements}

Paisly Symenuk: My name is Paisly, and I am a white settler with my great, great, great, great, great, grandparents coming from Scotland, Ireland, and Ukraine in the mid-1850s. My Nanny, Opa, Grandpa, and Gramma were all born and raised in Treaty 4 territory (southern Saskatchewan). I was born, raised, and completed nursing school in Treaty 6 territory (Edmonton). My journey in this work first began after reading about the Charles Camsell Hospital. Unknowingly, only 12 years after this institution was closed, I attended high school

VOL. 2(1) 
less than 5 minutes away. I am afforded a substantial opportunity to speak boldly about white supremacy in my everyday life and work, but never to experience violence or resistance relating to my racial identity. I remain committed to disrupting, decentering, and divesting from whiteness in nursing and wider society.

Dawn Tisdale: My name is Dawn Tisdale RN, BSN, MSN (in progress). I am of Mi'kmaq, Acadian and European ancestry (Irish, Ukrainian). My grandmother, Florence Roy, was born on the territory of the Bad River Band of the Lake Superior Tribe of Chippewa Indians (Northern Wisconsin) and is of Mi'kmaq ancestry from the Wabanski Confederacy (Bathurst, New Brunswick). My family's connection to our Indigeneity and culture was greatly impacted by assimilative processes in the Canadian state. As an Indigenous nurse, I hope to build more capacity for Indigenous nursing Knowledge and leadership within our current systems and build on the legacy of Indigenous nurses that have created tremendous change in the face of adversity. All my relations.

Danielle H. Bourque Bearskin: I am known as Danielle Helen Bourque Bearskin, great granddaughter of Marianne Bearskin of Beaver Lake Cree Nation in Treaty 6 Territory, Alberta. This is where nohkum (my Grandmother) Elma Bourque Bearskin and nikawiy (my Mother) Raymonde Lisa Bourque Bearskin, also known as "Mona", were born. I also come from mixed European descent, my biological father was a third generation settler of Canada. Although, I was primarily exposed to my Indigenous culture and raised to be a resilient Nehiyaw Iskwew (Cree Woman), I acknowledge the privilege I hold as a white passing Nehiyaw. With that privilege, I vow to uphold the voices of my Indigenous sisters and brothers who do not have the same benefit as I have to take up space without resistance.

Tessa Munro: My name is Tessa Munro, and I am a White settler with European ancestry from Scotland Ireland England and Norway. I grew up on Sinixt territory and have lived for the past seven years on the lands of the WSÁNEĆ and Lkwungen-speaking peoples. Recognizing my family's relationship to both the historical and ongoing impacts of settler colonialism has guided me to this important work of decolonization. I am humbled and honoured to be on this journey and am always in a place of learning and unlearning. 


\section{References}

Allan, B., \& Smylie, J. (2015). First Peoples, second class treatment: The role of racism in the health and well-being of Indigenous Peoples in Canada. Wellesley Institute.

APTN National News. (2018, January 30). Survivors of Indian hospitals seeking \$1.1B in damages. APTN National News. https://aptnnews.ca/2018/01/30/survivor s-indian-hospitals-seeking-1-1bdamages/

Blackstock, C., Trocmé, N., \& Bennett, M. (2004). Child maltreatment investigations among Aboriginal and non-Aboriginal families in Canada. Violence Against Women, 10(8), 901916. https://doi.org/10.1177/1077801204266 312

Boyer, Y. (2017). Healing racism in Canadian health care. CMAJ, 189, e1408-e1409. https://doi.org/10.1503/cmaj.171234

Boyer, Y., \& Bartlett, J. (2017). External review: Tubal ligation in the Saskatoon health region: The lived experience of Aboriginal women. https://www.saskatoonhealthregion.ca/D ocumentsInternal/Tubal_Ligation_inthe SaskatoonHealthRegion_the_Lived_Exp erience_of_Aboriginal_Women_Boyera ndBartlett_July_22_2017.pdf

Canadian Nurses Association. (1968). The leaf and the lamp. https://www.cna-aiic.ca/$/ \mathrm{media} / \mathrm{cna} /$ page-content/pdffr/the_leaf_and the lamp_e.pdf?la $=$ en $\&$ hash $=5 \mathrm{C} 007 \mathrm{~F} 2 \mathrm{C} 58 \overline{6} \mathrm{DB} 8 \overline{\mathrm{A}} 1 \mathrm{BA} 1501 \mathrm{C} 9$ 780A7F4E785FB263

DiAngelo, R. (2018). White fragility: Why it's so hard for white people to talk about racism. Beacon Press.
Drees, L. M. (2013). Healing histories: Stories from Canada's Indian hospitals. University of Alberta Press.

Dyck, E. (2013). Facing eugenics: Reproduction, sterilization, and the politics of choice. University of Toronto Press.

Finkelman, A. W. \& Kenner, C. (2009). Professional nursing concepts: Competencies for quality leadership. Jones \& Bartlett Learning.

Gordon, S., \& Nelson, S. (2005). An end to angels. American Journal of Nursing, 105(5), 62-69.

www.jstor.org/stable/29745732

Green, B. N., Johnson, C. D., \& Adams, A. (2006). Writing narrative literature reviews for peer-review journals: Secrets of the trade. Journal of Chiropractic Medicine, 5, 101-117. https://doi.org/10.1016/S08993467(07)60142-6

Hallam, J. (2000). Nursing the image: Media, culture, and professional identity. Routledge.

Hardy v. The Attorney General of Canada, T143-18 (2018)

"Indian Health Services". (1951, May). The Canadian Nurse, 47(5), 333.

Indigenous Services Canada. (n.d.). Indigenous children in foster care. Census 2016 data. https://www.sacisc.gc.ca/eng/1541187352297/15411873 92851

Kalisch, P., \& Kalisch, B. (2005). Perspectives on improving nursing's public image. Nursing Education Perspectives, 26(1), 10-17. 
LeBeuf, M.-E. (2011). The role of the Royal Canadian Mounted Police during the Indian Residential School system. Royal Canadian Mounted Police (RCMP). http://publications.gc.ca/collections/coll ection_2011/grc-rcmp/PS64-71-2009eng.pdf

Lux, M. K. (2016). Separate beds: A history of Indian hospitals in Canada, 1920s1980s. University of Toronto Press.

Lux, M. K. (2018). Indian hospitals. The Canadian Encyclopedia. https://www.thecanadianencyclopedia.ca /en/article/indian-hospitals-in-canada

Miller, J. R. (2020). Residential Schools in Canada. The Canadian Encyclopedia. https://www.thecanadianencyclopedia.ca /en/article/residential-schools

National Inquiry into Missing and Murdered Indigenous Women and Girls (NIMMIWG). (2019a). Reclaiming power and place: The final report of the National Inquiry into Missing and Murdered Indigenous Women and Girls - Volume 1a. https://www.mmiwgffada.ca/wpcontent/uploads/2019/06/Final_Report Vol_1a-1.pdf

National Inquiry into Missing and Murdered Indigenous Women and Girls (NIMMIWG). (2019b). Reclaiming power and place: The final report of the National Inquiry into Missing and Murdered Indigenous Women and Girls - Volume 1b. https://www.mmiwgffada.ca/wpcontent/uploads/2019/06/Final_Report Vol_1b.pdf

Nestel, S. (2012). Colour coded health care: The impact of race and racism on Canadians' health. Wellesley Institute. http://www.wellesleyinstitute.com/healt h-care/colour-coded-health-care-the- impact-of-race-and-racism-oncanadians-health/

Palmater, P. (2018, February 15). Truth and Reconciliation in Canada: If it feels good, it's not reconciliation. 2018 Woodrow Lloyd Lecture, Faculty of Arts, University of Regina, Regina, Canada.

Pike, A. (2001). Entering collegial relationships. In J. Dochterman \& H. Grace (Eds.), Current issues in nursing (6th ed., pp. 448-452). Mosby.

Public Health Agency of Canada. (2019). Provincial and territorial child protection legislation and policy 2018. https://www.canada.ca/content/dam/pha caspc/documents/services/publications/he alth-risks-safety/provincial-territorialchild-protection-legislation-policy2018/64-03-18-2245 ChildProtection_EN-FINALE2.pdf

Reading, C. L. (2018). Structural determinants of Aboriginal Peoples' health. In M. Greenwood, S. de Leeuw, N. Lindsay, \& C. Reading (Eds.), Determinants of Indigenous Peoples health beyond the social (2nd ed., pp. 3-17). Toronto: Canadian Scholars Press.

Crown-Indigenous Relations and Northern Affairs. (n.d.). People to people, nation to nation: Highlights from the report of the Royal Commission on Aboriginal people. https://www.rcaanccirnac.gc.ca/eng/1100100014597/15725 47985018

Sinclair, R. (2016). The Indigenous child removal system in Canada: An examination of legal decision-making and racial bias. First Peoples Child \& Family Review, 11(2), 8-18. https://fpcfr.com/index.php/FPCFR/artic le/view/310 


\section{The Canadian Journal of Critical Nursing Discourse}

See it. Speak it. Write it. Change it.

Smith, K. M. (2019). Facing history for the future of nursing. Journal of Clinical Nursing, 1-2. https://doi.org/10.1111/jocn.15065

Stevens, E. E., Patrick, T. E., \& Pickler, R. (2009). A history of infant feeding. The Journal of Perinatal Education, 18(2), 32-39. http://doi.org/10.1624/105812409X4263 14

Stote, K. (2015). An act of genocide: Colonialism and the sterilization of Aboriginal women. Fernwood Publishing.

Summers, S. \& Summers, H. J. (2015). Saving lives: Why the media's portrayal of nursing puts us all at risk. University of Oxford Press.

ten Hoeve, Y., Jansen, G., \& Roodbol, P. (2014). The nursing profession: Public image, self-concept and professional identity. A discussion paper. Journal of Advanced Nursing, 70(2), 295-309. https://doi.org/10.1111/jan.12177

Tisdale, D. \& McArthur, G. (2020). Indigenous health. In L. Leeseberg-Stamler, L. Yiu, A. Dosani, J. Etowa, \& C. van DaalenSmith (Eds.), Community health nursing: A Canadian perspective (5th ed., pp. 406-425). Pearson Canada.

Tisdale, D. \& Symenuk, P. M. (2020). Human rights and nursing codes of ethics in Canada 1952-2017. Nursing Ethics, 112. https://doi.org/10.1177/0969733020906 606

Truth and Reconciliation Commission of Canada. (2015a). Honouring the truth, reconciling the future: Summary of the final report of the Truth and Reconciliation Commission of Canada. http://nctr.ca/assets/reports/Final\%20Re ports/Executive_Summary_English_We b.pdf

Truth and Reconciliation Commission of Canada. (2015b). A knock on the door: The essential history of residential schools from the Truth and Reconciliation Commission of Canada, edited and abridged. University of Manitoba Press.

Truth and Reconciliation Commission of Canada. (2015c). The survivors speak: A report of the Truth and Reconciliation Commission of Canada. http://publications.gc.ca/collections/coll ection_2015/trc/IR4-5-2015-eng.pdf

UN General Assembly. (2014). Report of the Special Rapporteur on the rights of Indigenous People, James Anaya. http://unsr.jamesanaya.org/docs/countrie s/2014-report-canada-a-hrc-27-52-add2-en.pdf

Watson, I. (2016). First Nations and the colonial project. Inter Gentes: The McGill Journal of International Law \& Legal Pluralism, 1(1), 30-39.

http://intergentes.com/wpcontent/uploads/2016/11/First-Nationsand-the-Colonial-Project_Watson.pdf 
See it. Speak it. Write it. Change it.

Search Strategy

\section{Appendix A}

\begin{tabular}{|c|c|c|c|c|}
\hline Search \# & Term \#1 & Term \#2 & Term \#3 & Term \#4 \\
\hline 1 & "Indian hospital*" NOT "India" & \multirow{5}{*}{$\begin{array}{l}\text { Indigenous OR First } \\
\text { Nation* OR } \\
\text { Aboriginal* OR } \\
\text { Metis* OR Inuit* }\end{array}$} & \multirow[t]{5}{*}{$\begin{array}{l}\text { Canada* OR } \\
\text { Canadian* }\end{array}$} & \multirow[t]{5}{*}{ nurs* } \\
\hline 2 & "Residential school*" & & & \\
\hline 3 & $\begin{array}{l}\text { "Child apprehen*" OR "Children } \\
\text { apprehen*" OR "Apprehension of child*" } \\
\text { OR "Children in care" OR "60"s Scoop*" } \\
\text { OR "Sixties Scoop" OR "child welfare*" }\end{array}$ & & & \\
\hline 4 & $\begin{array}{l}\text { "Forced sterilization" OR "steriliz*” OR } \\
\text { "eugenic*” OR "tubal ligation*” OR } \\
\text { "family planning" OR "genetic counsel*" }\end{array}$ & & & \\
\hline 5 & $\begin{array}{l}\text { "Missing and Murdered Indigenous } \\
\text { Women*" OR "Missing \& Murdered } \\
\text { Indigenous Women*" OR "Murdered and } \\
\text { Missing Indigenous Women*" OR } \\
\text { "Murdered and Missing Indigenous } \\
\text { Women*" OR "MMIW" OR "MMIWG" } \\
\text { OR "Missing women*" OR "murdered } \\
\text { women*" }\end{array}$ & & & \\
\hline
\end{tabular}

